\title{
Selection of efficient rhizobial symbionts for Cratylia argentea in the cerrado biome
}

\author{
Seleção de rizóbios eficientes na simbiose com Cratylia argentea no bioma cerrado
}

\author{
Giovanna Moura Calazans ${ }^{\mathrm{I}}$ Christiane Abreu de OliveiraII \\ José Carlos Cruz ${ }^{\mathrm{II}}$ Walter José Rodrigues Matrangolo"I Ivanildo Evódio Marriel ${ }^{\mathrm{I}^{*}}$
}

ABSTRACT

Cratylia argentea is a leguminous shrub native to the cerrado, which has great potential for forage production and recovery of degraded areas. This study aimed to isolate, characterize, and select efficient rhizobial strains in symbiosis with Cratylia argentea. Rhizobacteria were isolated from the nodules of 12-month-old plants and cultivated in pots containing cerrado soil. Twenty-five bacterial strains were obtained, which displayed extensive variability with respect to morphological and symbiotic characteristics. Cratylia argentea seeds were planted in pots containing $5 \mathrm{~kg}$ of cerrado soil and maintained in the greenhouse. The treatments consisted of 25 rhizobial isolates, two controls (without nitrogen and without inoculation), with or without nitrogen fertilization $\left(5 \mathrm{mgN} \cdot\right.$ plant $^{-1} \cdot$ week $\left.^{-1}\right)$, and four replications. Plants were cultivated for 150 days after planting seeds to evaluate nodule number, nodule dry weight, shoot and root dry weight, shoot and root $N$ content, and relative and symbiotic efficiency. Thirteen isolates improved shoot dry weight (up to 65.8\%) and shoot nitrogen concentration (up to 76\%) compared with those of control treatments. Two isolates, 4 (CR42) and 22 (CR52), conferred higher symbiotic efficiency values of approximately $20 \%$. Therefore, these two rhizobial isolates displayed the highest potential as beneficial inoculants to optimize the symbiotic efficiency for Cratylia and to increase the incorporation of nutrients and biomass into the productive system in the cerrado.

Key words: biological fixation, legumes, cerrado.

RESUMO

Cratylia argentea é uma leguminosa arbustiva nativa do cerrado, com alto potencial para produção de forragem e recuperação de áreas degradadas. Este trabalho teve como objetivo isolar, caracterizar e selecionar estirpes de rizóbios eficientes na simbiose com $\boldsymbol{C}$. argentea. As bactérias foram isoladas de nódulos de plantas com 12 meses de idade, cultivadas em solo de cerrado, em vasos. Foram obtidas 25 estirpes, que apresentaram alta variabilidade em relação às características morfológicas $e$ simbióticas. Sementes de $\boldsymbol{C}$. argentea foram plantadas em potes contendo $5 \mathrm{~kg}$ de solo de cerrado, e mantidos em casa de vegetação. Os tratamentos consistiram em 25 isolados, controle (sem $\mathrm{N}$ e sem inoculação) e adubação nitrogenada (5mgN $\cdot$ planta $^{-1} \cdot$ semana $\left.^{-1}\right)$, em quatro repetições. As plantas foram colhidas 150 dias após o plantio para avaliar o número e a massa seca de nódulos, a massa seca e concentração de nitrogênio da parte área e das raízes. Foram calculadas as eficiências relativas e simbióticas. Treze estirpes se destacaram quanto ao acúmulo de massa seca (até $65,8 \%$ ) e acúmulo de nitrogênio (até $76 \%$ ), da parte aérea, em relação ao tratamento controle. Dentre estas, as estirpes 4 e 22 apresentaram maiores eficiencias simbióticas (em torno de 20\%). Portanto, estas estirpes apresentaram potencial para formulação de inoculantes, visando otimizar o processo simbiótico rizóbioCratylia e a incorporação de biomassa e nutrientes em sistema produtivos no cerrado.

Palavras-chave: fixação biológica, leguminosa, cerrado.

\section{INTRODUCTION}

The cerrado is the second-largest brazilian biome; it covers twelve states and occupies an area equivalent to approximately $25 \%$ of the national territory. The cerrado contains an abundant variety of endemic species and is one of the world's biodiversity hotspots, which has made it a global conservation priority (MYERS et al., 2000). However, this biome has undergone deforestation in approximately 50\% of its area, and only $30 \%$ of its original biodiversity remains. These losses are primarily due to urban

'Fundação de Ensino Superior de Itabira (FUNCESI), Itabira, MG, Brasil.

IIEmbrapa Milho e Sorgo (CNPMS), Rod. MG 424, km 45, 35701-970, Centro Universitário de Sete Lagoas (UNIFEMM), Sete Lagoas, MG, Brasil. E-mail: ivanildo.marriel@embrapa.br. "Corresponding author. 
expansion and the proliferation of agricultural and mining activities. The importance of the cerrado in brazilian agribusiness is significant, considering that this biome accounts for more than $50 \%$ of the national grain and meat production (MARQUES et al., 2014).

Successful strategies for the recovery of degraded areas recommend that native species of the biome of interest are used for revegetation. For the brazilian cerrado, plants of the legume family (Fabaceae, Papilionaceae) are the preferred native species, especially leguminous shrubs and trees. These plants form symbiotic relationships with nitrogen- fixing bacteria, called rhizobacteria, which enhanced the inputs of carbon, nitrogen, and nutrient cycling, and ultimately facilitate the production of greater biomass while reducing the need for nitrogenous fertilizers (CHAER et al., 2011; MARQUES et al., 2014).

Cratylia argentea (Desv.) O. Kuntze, also known as "camaratuba, copada, or cipó-prata", is a legume (Fabaceae, Papilloneidae) and is an endemic leguminous species in central Brazil (native of cerrado and caatinga), Bolivia, and Peru (GALDINO et al., 2010; TEIXEIRA et al., 2010; MARQUES et al., 2014; VALLES DE LA MORA et al., 2014). Cratylia argentea has great potential as a forage plant because it is a deep-rooting shrub with high protein biomass, produces abundant seeds with excellent germination, has strong regrowth capacity, tolerates nutrientdeficient and acidic soils, and is drought resistant owing to its vigorous root development (LASCANO et al., 2002; REYES et al., 2007; ALPALA et al., 2010; CASTILLO-GALLEGOS et al., 2013). These characteristics support its use as aforage plant for agro-pastoral systems and for recovery of degraded areas (MARQUES et al., 2014).

Biological nitrogen fixation (BNF) optimization depends on rhizobial inoculation of the legume seeds during planting. The inoculants should be rhizobial strains with high performance, including strong survival, competitiveness, and host plant root colonization, compared with the performance of native strains at the sites of interest (STRALIOTTO et al., 2002). Edaphic factors such as acidity $(\mathrm{pH})$ and aluminum concentration can limit nodule formation and activity, and plant nitrogen assimilation (HUNGRIA \& VARGAS, 2000). CHAER et al. (2011) reported that some N-fixing rhizobial species have preferences and specificities for different legume species, so it is crucial to select optimized strains for specific applications. CHAGAS JR (2010) noted that different rhizobial strains display optimum performance under different environmental conditions, and it is necessary to select rhizobia that are adapted to the environmental conditions in the ecosystem of interest.

Studies on the selection, phenotypic characterization, and availability of rhizobial strains for Cratylia argentea are limited to a few institutions such as the International Center for Tropical Agriculture (CIAT) in Cali, Colombia, and Embrapa National Center for Research on Agrobiology in Rio de Janeiro, Brazil. In general, the specificity of microsymbionts versus macrosymbionts becomes relevant particularly in studies of new isolates to evaluate their nodulation and symbiotic efficiencies in the cerrado biome. MARQUES et al. (2014) used Cratylia argentea for recovery of degraded areas in the cerrado, and only one individual in the field was associated with native rhizobia. These previous studies strengthen the relevance of the current research. Thus, the aim of this study was to isolate, characterize, and select optimized rhizobial strains for BNF and symbiosis with Cratylia argentea utilized for forage production and/or recovery of degraded areas in the brazilian cerrado.

\section{MATERIALS AND METHODS}

Rhizobial isolation, cultivation, and phenotypic characterization

These studies were conducted in a greenhouse and in a laboratory at the Embrapa Maize and Sorghum, Sete Lagoas, Minas Gerais, Brazil. Nodules were obtained from Cratylia argentea seedlings (12 months old, grown in cerrado soil), which were used as trap plants (XAVIER et al., 1997). Colonies were isolated and characterized according to the methods reported by VINCENT (1970) and HUNGRIA \& ARAÚJO (1994). The isolated strains were cultured on yeast mannitol agar (YMA; pH 6.8) plates containing Congo red, which were incubated for 96 hours at $28^{\circ} \mathrm{C}$ before strain characterization. The following phenotypic characteristics were observed: COL, color (light pink, orange, red, or colorless); APP, appearance (homogeneous or heterogeneous); TRANS, transparency (opaque, translucent, or transparent); SHA, shape (circular or irregular); EDG, edge type (full or irregular); ELA, elasticity (low, moderate, or high); $\mathrm{ADH}$, adherence to the platinum loop (adherent or non-adherent); MUC, mucus consistency (mucoid, viscous, watery, orbutyrous); SUR, surface (smooth or rough); GRO, growth period [fast (within 4 days) or slow (more than 4 days)] and growth diameter $(\varnothing)(<1 \mathrm{~mm}$, $1-2 \mathrm{~mm},>2 \mathrm{~mm})$. Physiological characteristics were 
evaluated by transferring microorganisms into medium containing bromothymol blue to measure culture $\mathrm{pH}$ (acid, neutral, and alkaline). This protocol enabled selection of 25 strains to test for symbiotic efficiency with the host plant.

Test for symbiotic efficiency of rhizobial isolates

To evaluate the symbiotic efficiency of the isolated rhizobial strains, soil samples were collected in three different areas of the cerrado in Sete Lagoas. Soil samples were classified as dystrophic dark-red latosol and cerrado. Soil samples were transferred without sterilization into pots with $5 \mathrm{~kg}$ capacity in a greenhouse $\left(28^{\circ} \mathrm{C}\right.$; natural light in summer, humidity $65 \%$ ). The experimental treatments were as follows: each selected rhizobial strain, two controls (without nitrogen and without inoculation), and with and without nitrogen fertilization $\left(5 \mathrm{mg} \mathrm{N} \cdot\right.$ plant $^{-1} \cdot$ week $\left.^{-1}\right)$ in the form of ammonium nitrate. Seeds were disinfected superficially with alcohol $(70 \%)$ for $30 \mathrm{~s}$, followed by hypochlorite $(0.5 \%)$ for $10 \mathrm{~min}$ and sterile distilled water and then inoculated with $2 \mathrm{~mL}$ of enriched bacterial suspension $\left(10^{8}\right.$ cells $\left.\cdot \mathrm{mL}^{-1}\right)$ in YMA medium (For 1L: Yeast extract 1.0g; Mannitol, 10g; Dipotassium phosphate, 0.5g; Magnesium sulfate, $0.2 \mathrm{~g}$; Sodium chloride, $0.1 \mathrm{~g}$; Calcium carbonate, $1.0 \mathrm{~g}$; Agar, $15.0 \mathrm{~g}$ ). Experimental pots were placed using a randomized block design with four replications. Seedlings were thinned to a final density of three plants per pot. All treatments, including controls treatments (without nitrogen and without inoculation), received half strength nutrient solution without nitrogen once a week according to HUNGRIA \& ARAÚJO (1994). Plants were irrigated with distilled water when necessary to maintain the humitidy.

Plants were harvested 150 days after seeds were planted. Plants were evaluated for number of nodules $(\mathrm{NN})$, root dry weight (RDW), shoot dry weight (SDW), nodule dry weight (NDW), and $\mathrm{N}$ content of shoot and roots. For dry weight measurements, plants were dried in an oven at $60^{\circ} \mathrm{C}$ until they achieved a constant weight. Relative efficiency $(R E f)$ of each strain was calculated according to Equation (1):

$R E f=\mathrm{SDW}$ inoculated treatment / SDW N treatment $\mathrm{x} 100$

Where SDW $=$ shoot dry weight of the inoculated plants and SDW $\mathrm{N}$ treatment = shoot dry weight of plants treated with nitrogen fertilization. Plant symbiotic efficiency (SE) was calculated according to Equation (2):

$\mathrm{SE}=[($ Ntotal fixed - NtotalCT $) /($ Ntotal NT NtotalCT) x 100]
Where $\mathrm{N}$ total fixed = total nitrogen content of the inoculated plants; Ntotal CT = total nitrogen content of the control plants without nitrogen fertilization; and N total NT = total nitrogen content of the control plants treated with nitrogen fertilization.

Results were subjected to variance analysis. Averages were compared by the Scott-Knott test (5\% probability) using the statistical program SISVAR version 5.3.

\section{RESULTS AND DISCUSSION}

Isolation and phenotypic characterization of rhizobia from Cratylia argentea

The Cratylia argentea trap plants displayed a large NN (59-76 nodules per pot), which were established by natural rhizobial populations in the soil. The start of nodulation was observed at 70 days after seed germination. At that time, nodules were forming primarily in the secondary roots, but also in the main root. These results differed from those reported by OLIVEIRA et al. (1998), who stated that Cratylia argentea nodulation occurred 100 days after seed germination and only in secondary roots.

Three healthy nodules (those with typical internal pink color) were selected for plating from each plant. The characteristic pink color indicated the presence of leg hemoglobin, which is the protein that transports and releases oxygen in nodules under adequate partial pressure; oxygen is required for nitrogenase activity and nitrogen fixation in mature symbiotic nodules (VINCENT, 1970).

Phenotypic characterization of the rhizobial isolates detected substantial morphological variability among different colonies for all evaluated parameters except transparency and surface (Figure 1). All isolates were translucent and had smooth surfaces. The observed colonies exhibited predominantly light pink color (76\%), circular shape $(100 \%)$, full edge $(100 \%)$, and mucoid consistency $(60 \%)$. Only $16 \%$ of isolates displayed elasticity, whereas $92 \%$ of isolates easily adhered to the platinum loop. Morphological characteristics provide important information that can be used to determine the identity and group classification of isolated strains (VINCENT, 1970), symbiotic efficiency between rhizobia and host plants, and rhizobial diversity in a particular ecosystem community (SANTOS et al., 2007). CHAGAS JR et al. (2010) proposed that analyses of morphological and physiological differences between microorganisms is the crucial first step for identifying new taxonomic groups, and results can be used to guide subsequent 


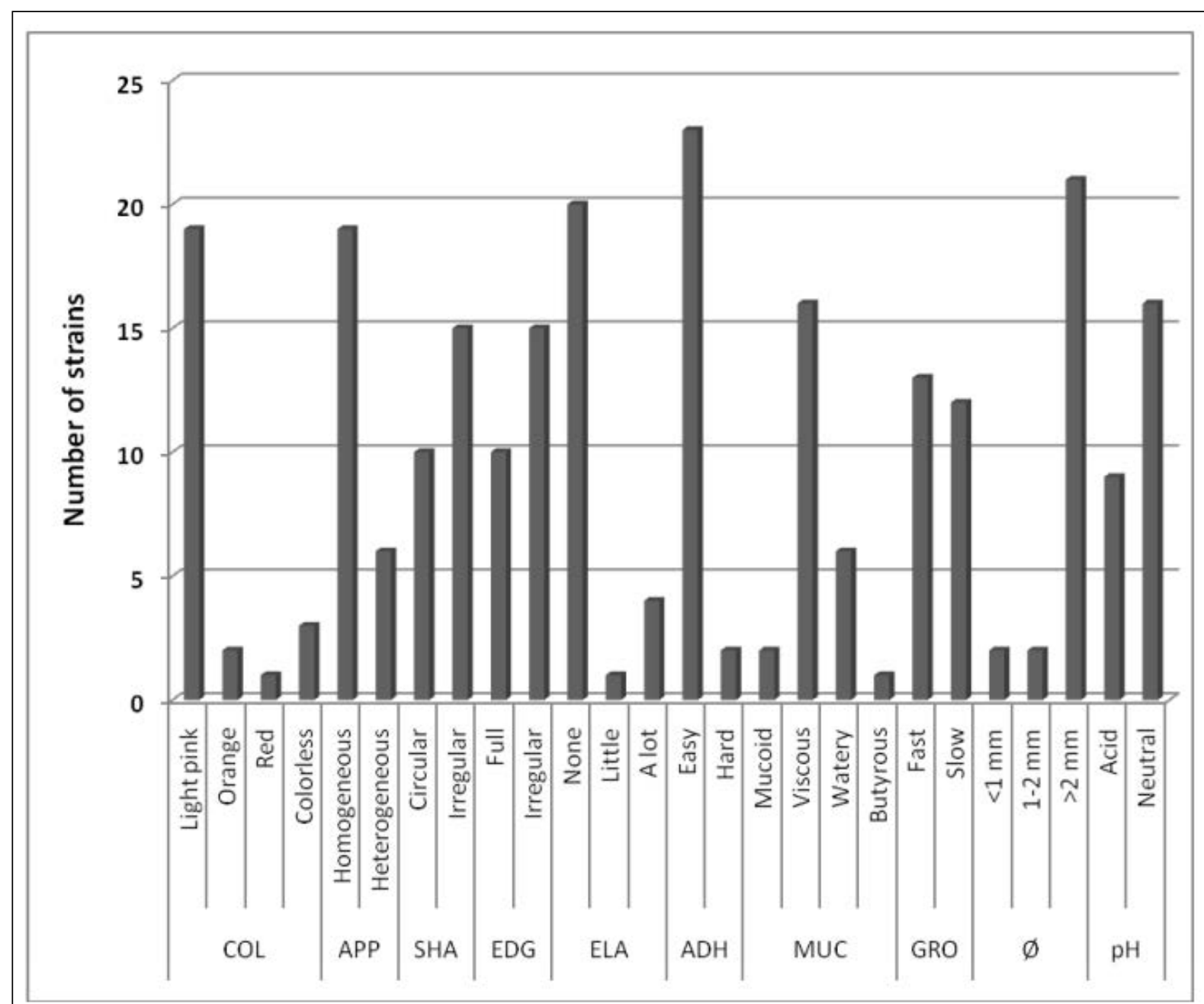

Figure 1 - Distribution of morphological characteristics for rhizobial isolates obtained from Cratylia argentea root nodules: color (COL); appearance (APP); shape (SHA); edge type (EDG); elasticity (ELA); adherence to the platinum loop (ADH); mucus consistency (MUC); growth period (GRO); colony diameter (Ø); and $\mathrm{pH}$.

analyses such as molecular genetic properties. In the present research, morphological analysis resulted in the selection of 25 rhizobial strains (Table 1). These strains displayed morphological and physiological differences, and were evaluated in symbiosis with Cratylia argentea plants.

Growth rate of 25 selected strains differed, with 13 showing fast growth (up to 4 days) and 12 showing slow growth (more than 4 days). These results indicated that isolated strains that are competent to nodulate Cratylia argentea display significant metabolic diversity. Another interesting finding was that 14 of the isolated strains maintained the $\mathrm{pH}$ of the culture medium at approximately 7.0, whereas nine strains slightly acidified the culture medium $(\mathrm{pH}$ approximately 6.0), and two strains strongly acidified the culture medium ( $\mathrm{pH}$ approximately 4.0). NORRIS (1965) proposed that rhizobial acid release functions as an adaptive mechanism to adverse conditions. Our results are consistent with those of TEIXEIRA et al. (2010), who evaluated rhizobial strains of Cratylia mollis in caatinga soil and reported that most isolates had rapid growth and did not alter the medium $\mathrm{pH}$.

Selection of efficient rhizobia in symbiosis with Cratylia argentea

Table 1 presents the morphological, physiological, and symbiotic characteristics (nodulation, growth, and nitrogen content) of Cratylia argentea plants subjected to different treatments and 
Table 1 - Physiological characteristics of Cratylia argentea (three plants per pot) that were subjected to control treatment (CT), treatmen1 with 25 rhizobial strains (1 to 25), and nitrogen fertilizer treatment (NT). Mean values for number of nodules per pot $(\mathrm{NN}){ }^{* *}$, nodule dry weight per pot (NDW), shoot dry weight per pot (SDW), root dry weight per pot (RDW), shoot nitrogen content per poi (NSH), and root nitrogen content per pot (NRO). The relative efficiency (REf) and symbiotic efficiency (SE) for each test is presented.

\begin{tabular}{|c|c|c|c|c|c|c|c|c|c|c|c|c|c|c|}
\hline \multirow{2}{*}{$\begin{array}{l}\text { Test/Strain } \\
\text { CT }\end{array}$} & \multicolumn{2}{|c|}{------NN------ } & \multicolumn{6}{|c|}{----NDW (g)--- ---SDW (g)---- ----RDW (g)----- } & \multicolumn{4}{|c|}{----NSH (g)----- -----NRO (g)----- } & \multirow{2}{*}{$\begin{array}{l}\text { REf }(\%) \\
-\end{array}$} & \multirow{2}{*}{$\begin{array}{l}\text { SE }(\%) \\
-\end{array}$} \\
\hline & 67 & $\mathrm{~b}$ & 0.27 & $\mathrm{~b}$ & 5.96 & c & 4.59 & a & 0.17 & $\mathrm{c}$ & 0.08 & $\mathrm{c}$ & & \\
\hline 1 & 133 & a & 0.50 & a & 8.40 & $\mathrm{~b}$ & 6.31 & a & 0.24 & $\mathrm{~b}$ & 0.11 & $\mathrm{~b}$ & 44.63 & 10.92 \\
\hline 2 & 137 & a & 0.43 & $\mathrm{~b}$ & 8.12 & b & 6.31 & a & 0.23 & $\mathrm{~b}$ & 0.14 & $\mathrm{~b}$ & 43.15 & 12.29 \\
\hline 3 & 119 & $\mathrm{a}$ & 0.61 & a & 9.51 & b & 6.67 & a & 0.26 & b & 0.14 & b & 50.5 & 15.59 \\
\hline 4 & 116 & $\mathrm{a}$ & 0.61 & $\mathrm{a}$ & 9.88 & b & 6.73 & a & 0.28 & b & 0.15 & $\mathrm{~b}$ & 52.48 & 19.59 \\
\hline 5 & 95 & $\mathrm{a}$ & 0.54 & $\mathrm{a}$ & 9.66 & $\mathrm{~b}$ & 6.17 & a & 0.29 & b & 0.13 & $\mathrm{~b}$ & 51.32 & 17.85 \\
\hline 6 & 77 & $\mathrm{~b}$ & 0.37 & b & 7.12 & $\mathrm{c}$ & 5.95 & a & 0.22 & $\mathrm{~b}$ & 0.14 & $\mathrm{~b}$ & 37.81 & 10.77 \\
\hline 7 & 79 & $\mathrm{~b}$ & 0.57 & $\mathrm{a}$ & 8.70 & b & 5.73 & $\mathrm{a}$ & 0.26 & b & 0.12 & b & 46.23 & 14.8 \\
\hline 8 & 92 & $\mathrm{a}$ & 0.51 & $\mathrm{a}$ & 6.67 & $\mathrm{c}$ & 7.51 & $\mathrm{a}$ & 0.23 & b & 0.18 & $\mathrm{~b}$ & 35.43 & 17.19 \\
\hline 9 & 104 & a & 0.50 & a & 8.17 & b & 5.89 & a & 0.23 & b & 0.13 & b & 43.42 & 12.23 \\
\hline 10 & 95 & a & 0.52 & a & 8.42 & $\mathrm{~b}$ & 6.33 & a & 0.25 & $\mathrm{~b}$ & 0.15 & $\mathrm{~b}$ & 44.71 & 14.93 \\
\hline 11 & 75 & $\mathrm{~b}$ & 0.49 & a & 7.37 & c & 6.40 & a & 0.25 & $\mathrm{~b}$ & 0.14 & $\mathrm{~b}$ & 39.16 & 15.17 \\
\hline 12 & 40 & c & 0.22 & $\mathrm{~b}$ & 4.30 & d & 2.25 & $\mathrm{~b}$ & 0.13 & c & 0.05 & d & 22.85 & -6.88 \\
\hline 13 & 80 & $\mathrm{~b}$ & 0.66 & $\mathrm{a}$ & 7.48 & c & 5.70 & a & 0.24 & $\mathrm{~b}$ & 0.12 & b & 39.72 & 11.35 \\
\hline 14 & 106 & $\mathrm{a}$ & 0.63 & $\mathrm{a}$ & 7.58 & c & 5.83 & a & 0.25 & b & 0.14 & b & 40.26 & 14.52 \\
\hline 15 & 49 & $\mathrm{c}$ & 0.27 & b & 4.34 & d & 1.90 & b & 0.13 & c & 0.04 & d & 23.04 & -7.61 \\
\hline 16 & 100 & $\mathrm{a}$ & 0.63 & a & 7.01 & c & 5.86 & a & 0.23 & b & 0.13 & b & 37.25 & 12.28 \\
\hline 17 & 83 & $\mathrm{~b}$ & 0.59 & a & 6.90 & c & 5.40 & a & 0.22 & b & 0.13 & b & 36.66 & 11.47 \\
\hline 18 & 107 & $\mathrm{a}$ & 0.71 & $\mathrm{a}$ & 8.16 & b & 5.60 & $\mathrm{a}$ & 0.26 & b & 0.13 & b & 43.37 & 13.7 \\
\hline 19 & 81 & b & 0.58 & a & 7.84 & $\mathrm{~b}$ & 5.68 & a & 0.25 & b & 0.12 & $\mathrm{~b}$ & 41.65 & 12.45 \\
\hline 20 & 68 & $\mathrm{~b}$ & 0.53 & a & 7.11 & c & 5.38 & a & 0.23 & b & 0.12 & $\mathrm{~b}$ & 37.77 & 11.08 \\
\hline 21 & 85 & $\mathrm{a}$ & 0.55 & a & 8.72 & $\mathrm{~b}$ & 5.72 & a & 0.29 & b & 0.12 & b & 46.32 & 17.1 \\
\hline 22 & 102 & $\mathrm{a}$ & 0.60 & a & 9.01 & b & 6.07 & $\mathrm{a}$ & 0.30 & b & 0.14 & b & 47.89 & 20.1 \\
\hline 23 & 49 & c & 0.27 & $\mathrm{~b}$ & 7.56 & c & 1.79 & b & 0.21 & b & 0.03 & d & 40.15 & 0.5 \\
\hline 24 & 113 & $\mathrm{a}$ & 0.67 & a & 6.55 & c & 6.07 & a & 0.22 & b & 0.13 & b & 34.8 & 10.58 \\
\hline 25 & 94 & $\mathrm{a}$ & 0.52 & $\mathrm{a}$ & 8.77 & b & 5.49 & $\mathrm{a}$ & 0.24 & b & 0.10 & b & 46.61 & 10.73 \\
\hline NT & 0 & d & - & & 18.82 & a & 7.57 & a & 0.98 & a & 0.26 & a & - & - \\
\hline
\end{tabular}

${ }^{*}$ Means with the same letter in the column do not differ significantly by the Scott-Knott test at $5 \%$ probability.

*** The number of nodules was transformed to $\log \mathrm{x}+1$ for statistical analysis.

harvested 150 days after germination. There were significant differences $(\mathrm{P}<0.05)$ between treatments for all parameters. The NN ranged between 40 and 137 per pot, and displayed various sizes and shapes. The majority of nodules were spherical, except for plants treated with nitrogen fertilization, which did not produce nodules. In general, individual nodule structures were produced, although a few siamese nodules also could be observed. These results are consistent with those of SCHEFFER-BASSO et al. (2000) for nodules of Adesmia araujoi (aloe), which also grows in acidic and low-fertility soils. Soil characteristics significantly influenced the rhizobial population in the soil (BALA et al., 2003). These results provided further evidence to support isolation and selection of specific Cratylia argentea rhizobia in cerrado soil.

Values for accumulation of SDW and RDW ranged from 4.30-9.88 and 1.79-7.51g per pot, respectively, depending on the isolated strain (Table 1). The highest values for SDW and RDW correspond to biomass increases of $65.8 \%$ and $63.6 \%$, respectively, compared with those of controls (without nitrogen fertilizer and without inoculation). However, these values represented $52.5 \%$ of the SDW and $88.9 \%$ of the RDW, respectively, of Cratylia argentea plants treated with nitrogen fertilizer.

Nitrogen accumulation in the shoot (NS) and in the root (NR) ranged from $0.13-0.30$ and 0.03 $0.18 \mathrm{~g}$ per pot, respectively. The highest values were 
equivalent to increases of $76 \%$ and $125 \%$, respectively, compared with those of the control treatment, and equivalent to $31 \%$ and $69 \%$, respectively, compared with those plants treated with nitrogen fertilizer.

The Scott-Knott test $(\mathrm{P}<0.05)$ indicated that 13 isolated strains $(1,2,3,4,5,7,9,10,18,19$, 21,22 , and 25) showed significantly greater SDW compared with those of other isolates and controls, although the SDW values were significantly lower than those of plants receiving nitrogen fertilizer. There were no significant differences among RDW values for any of the isolates or controls either with or without nitrogen fertilizer. The 13 isolates had NS and NR values that were significantly lower than those of plants treated with nitrogen fertilizer, but were higher than those of the controls. These combined results indicate that specific rhizobial strains can enhance BNF in Cratylia argentea. Therefore, it is important to genetically characterize new rhizobial isolates with specific host and environmental preferences to increase cerrado biomass production and promote natural reparation of environmentally degraded cerrado areas.

We computed Pearson correlations for total dry weight (TDW=SDW+RDW) and total nitrogen (NT) (0.911), for TN and the number of nodules (NN) (0.575), and for TDW and NN (0.607); all correlations were positive and significant. These results are in agreement with those reported by DÖBEREINER (1966), which suggested that nodulation can be used as an indicator of BNF efficiency. By contrast, OLIVEIRA et al. (1998) reported no significant correlation between the number of nodules and the fixed nitrogen content in Cratylia argentea tissues.

Table 1 presents the estimates for relative BNF efficiency based on our results for dry weight accumulation, symbiotic efficiency (SE), and plant nitrogen accumulation. The highest relative efficiency was $52.5 \%$, which was computed for plants inoculated with isolated strain 4 . The highest symbiotic efficiencies were computed for plants inoculated with isolated strain $4(19.6 \%)$ and strain $22(20.1 \%)$. The correlation between the relative BNF efficiency and the SE was positive and highly significant $(r=0.80, \mathrm{P}<0.01)$.

Strains with higher SE (strains 4 and 22) have growth rates that are significantly different than those of strains with negative SE (strains 12 and 15). Strains with higher SE grew rapidly, whereas strains 12 and 15 grew slowly. SANTOS et al. (2007) proposed that fast growth could confer a competitive advantage over others oil microbiota, which could partly explain our results.
Our combined results indicated that the selection of rhizobial strains for this legume is a promising practice to optimize Cratylia-rhizobial interactions, fixed organic nutrient concentrations, and biomass forage production in the cerrado environment. Results highlighted the potential of two selected strains (strains 4 and 22) to optimize efforts for legume biomass production and environmental reparation in the brazilian cerrado. The protocol developed in this study can be used as a guide for rhizobial strain selection to optimize BNF in Cratylia argentea.

\section{CONCLUSION}

There was extensive variability among rhizobial strains associated with Cratylia argentea in cerrado soil, which varied with respect to morphology, SE, and relative BNF efficiency. Most of the tested isolates maintained the soil at neutral $\mathrm{pH}$. Further testing and genetic characterization should be performed for 13 isolated strains that enhanced shoot biomass production (strains 1, 2, 3, 4, 5, 7, 9, 10, 18, $19,21,22$, and 25) and particularly for two strains, 4 (CR42) and 22 (CR52), that also had the highest symbiotic efficiencies. The 13 selected strains are promising for future field trials even in different local cerrado environments which aimed to optimizing $\mathrm{BNF}$ in the Cratylia argentea-rhizobia interaction.

\section{ACKNOWLEDGMENTS}

The authors thank the Conselho Nacional de Desenvolvimento Científico e Tecnológico $(\mathrm{CNPq})$ and the Fundação de Amparo à Pesquisa do Estado de Minas Gerais (FAPEMIG) for providing grants and financial support for this project.

\section{REFERENCES}

ALPALA, J.R. et al. Sowing systems of Cratylia argentea cultivar veranera in two localities of the valle del río Cauca, Colombia. Acta Agronomica, v.59, n.4, p.429434, 2010. Available from <http://www.scielo.org.co/scielo. php? script $=$ sci_arttext\&pid=S0120-28122010000400006\&lng $=$ en\&nrm=iso $>$. Accessed: Oct, 15. 2015.

BALA, A. et al. Nodulation of tree legumes and the ecology of their native rhizobial populations in tropical soils. Applied Soil Ecology, n.22, p.211-223, 2003. Available from: <http://dx.doi. org/10.1016/S0929-1393(02)00157-9>. Accessed: Sep. 18, 2015. doi: 10.1016/S0929-1393(02)00157-9.

CASTILlO-GALlEGOS, E. et al. Total dry matter yield and nutritive quality of leaves and young stems of four Cratylia argentea accessions in the humid tropics of Veracruz, Mexico. Avances en Investigación Agropecuaria, v.17, n.1, p.79-94, 2013. ISSN 0188789-0. 
CHAER, G.M. et al. Nitrogen-fixing legume tree species for the reclamation of severely degraded lands in Brazil. Tree Physiology, v.31, p.139-149, 2011. Available from: <http:// dx.doi.org/10.1093/treephys/tpq116>. Accessed: Oct. 10, 2015. doi: 10.1093/treephys/tpq116.

CHAGAS JR., A.F. et al. Phenotypic characterization of rhizobia strains isolated from Amazonian soils and symbiotic efficiency in cowpea. Acta Scientiarum Agronomy, v.32, n.1, p.161-169, 2010. Available from: $<$ http://dx.doi.org/10.4025/actasciagron. v32i1.900>. Accessed: Oct. 11, 2015. doi: 10.4025/actasciagron. v32i1.900.

DÖBEREINER, J. Evaluation of nitrogen fixation in legumes by the regression of total plant nitrogen with nodule weight. Nature, v.210, p.850-852, 1966. Available from: <http:// dx.doi.org/doi:10.1038/210850a0>. Accessed: Oct. 20, 2015. doi:10.1038/210850a0.

GALDINO, A.S. et al. Molecular characterization of Cratylia argentea accessions and its phylogenetic relationship with other legumes. Pesquisa Agropecuária Brasileira, v.45, n.8, p.846854, 2010. Available from: <http://dx.doi.org/doi:10.1590/S0100204X2010000800010>. Accessed: Oct. 12, 2015. doi: 10.1590/ S0100-204X2010000800010

HUNGRIA, M.; ARAÚJO, R.S. (Ed.). Manual de métodos empregados em estudos de microbiologia agrícola. Santo Antônio de Goiás: Embrapa-CNPAF, 1994. 560p.

HUNGRIA, M.; VARGAS, M.A.T. Environmental factors affecting $\mathrm{N}_{2}$ fixation in grain legumes in the tropics, with an emphasis on Brazil. Field Crops Research, v.65. p.151-164, 2000. Available from: <http://dx.doi.org/doi:10.1016/S0378-4290(99)00084-2>. Accessed: Sep. 18, 2015. doi:10.1016/S0378-4290(99)00084-2.

LASCANO, C. et al. Cultivar Veranera Cratylia argentea (Desvaux) O. Kuntze: Leguminosa arbustiva de usos múltiples para zonas con períodos prolongados de sequía em Colombia. Villavicencio: Corporación Colombiana de Investigación Agropecuaria (Corpoica) y Centro Internacional de Agricultura Tropical (CIAT), 2002. 28p.

MARQUES, T.E.D. et al. Growth of cerrado native species and of Vetiveria zizanioides in colluvium of gullies. Ciência Florestal, v.24, n.4, p.843-856, 2014. Available from: <http://dx.doi. org/10.1590/1980-509820142404005>. Accessed: Sep. 19, 2015. doi: 10.1590/1980-509820142404005.

MYERS, N. et al. Biodiversity hotspots for conservation priorities. Nature, v.403. p.853-858, 2000. Available from: <http://dx.doi. org/10.5902/1980509816584>. Accessed: Oct. 20, 2015. doi: $10.5902 / 1980509816584$

NORRIS, D.O. Acid production by Rhizobium a unifying concept. Plant and Soil, v.22, n.2, p.143-166, 1965. Available from: <http:// dx.doi.org/10.1007/BF01373988>. Accessed: Oct. 03, 2015. doi: 10.1007/BF01373988.

OLIVEIRA, F.L. et al. Seleção de estirpes de rizóbio para leguminosas Arachispintoie Cratyliaargentea. Seropédica, RJ: Embrapa-CNPAB, 1998. 19p.

REYES, S.N. et al. Biomass production and nutritive composition of Cratylia argentea under different planting densities and harvest intervals. Journal of Sustainable Agriculture, v.29, n.4, p.5-22, 2007. Available from: <http://dx.doi.org/10.1300/J064v29n04_03>. Accessed: Oct. 20, 2015. doi: 10.1300/J064v29n04_03.

SANTOS, C.E.R.S. et al. Diversity of rhizobiuns capable of forming nodules tropical legumes. Revista Brasileira de Ciências Agrárias, v.2, n.4. p.249-256, 2007.

SCHEFFER-BASSO, S.M. et al. Nodulation and biological nitrogen fixation in Adesmia araujoi Burk. Revista Brasileira de Agrociência, v.6, p.16-18, 2000.

STRALIOTTO, R. et al. Fixação biológica de nitrogênio. In: AIDAR, $H$. et al. Produção de feijoeiro comum em várzeas tropicais. Santo Antônio de Goiás: Embrapa Arroz e Feijão, 2002. p.122-153.

TEIXEIRA, F.C.P. et al. Characterization of indigenous rhizobia from caatinga. Brazilian Journal of Microbiology, v.41, n.1, p.201-208, 2010. Available from: <http://dx.doi.org/10.1590/ S1517-83822010000100029>. Accessed: Oct. 20, 2015. doi: $10.1590 / \mathrm{S} 1517-83822010000100029$.

VALLES-DE LA MORA, B. et al. Cratylia argentea: a potential fodder shrub in silvopastoral systems, yield and quality of accessions according to regrowth ages and climatic seasons. Revista Chapingo. Serie Ciencias Forestales y del Ambiente, v.20, n.2, p.277-293, 2014. Available from: <http://dx.doi. org/10.5154/r.rchscfa.2013.11.040>. Accessed: Oct. 22, 2015. doi: 10.5154/r.rchscfa.2013.11.040.

VINCENT, J.M. A manual for practical study of root nodule bactéria. Oxford: Blackwell Scient. Publ., 1970. 140p. (IBP Handbook, n.15).

XAVIER, G.R. et al. Protocolo operacional cultivo de plantaisca para isolamento de rizóbio a partir de nódulo de plantaisca. Seropédica, RJ: Embrapa-CNPAB, 1977. 7p. 